THE TYINALE BIBLICAL THEOLOGY LECTURE, 1979*

\title{
THE DELAY OF THE PAROUSIA
}

\author{
By Richard J. Bauckham
}

Early Christianity was both continuous and discontinuous with first-century Judaism. Its theology shared many features of contemporary Jewish thought, though these were given a distinctively Christian character by their relationship to Christianity's unique faith in Jesus Christ. As in the case of many other issues, an adequate account of the understanding of the delay of the parousia in early Christianity must reflect both the continuity and the discontinuity with Judaism.

In some respects the problem/1/ of the delay of the parousia was the same problem of eschatological delay which had long confronted Jewish apocalyptic eschatology; in other respects it was a new and distinctively Christian problem, in that the End was now expected to take the form of the parousia of Jesus Christ in whose death and resurrection God had already acted eschatologically. Our subject therefore needs to be approached from two angles: from its background in Jewish apocalyptic and in terms of its distinctively Christian characteristics. Within the limits of this lecture, I can attempt only one of these approaches, and I have chosen the former, both because almost all previous study has entirely neglected this approach,/2/ treating the delay of the parousia as a uniquely

* Delivered at Tyndale House, Cambridge, on July 6th, 1979.

1. By using the word 'problem' I do not mean to endorse the hypothesis (now generally abandoned) of a crisis of delay in early Christianity. I mean simply that the delay raised questions which had to be answered.

2. The only significant exception is the important work of A. Strobel, Untersuchungen zum eschatologischen Verzögerungsproblem auf Grund der spätjüdischurchristlichen Geschichte von Habakuk 2.2 ff. (Supplements to Novum Testamentum 2. Leiden: E. J. Brill, 1961). 
Christian issue,/3/ and also because it is only when we relate the Christian understanding of the delay to its Jewish apocalyptic background that we shall be able to appreciate its distinctively Christian features in their true significance. So if this lecture on biblical theology seems to linger rather long over Jewish extracanonical literature, I hope you will find that this procedure is justified by its contribution to an understanding of the New Testament.

\section{ESCHATOLOGICAL DELAY IN JEWISH APOCALYPTIC}

The problem of eschatological delay was familiar to Jewish apocalyptic from its earliest beginnings. It could even be said to be one of the most important ingredients in the mixture of influences and circumstances which produced the apocalyptic movement. In the face of the delay in the fulfilment of the eschatological promises of the prophets, the apocalyptic visionaries were those who believed most fervently that the promises remained valid and relevant. Despite appearances, God had not forgotten his people. His eschatological salvation, so long awaited, was coming, and now at last it was very close at hand. In almost all the apocalypses there is no mistaking both a consriousness, to some degree, of the problem of delay, in that the prophecies had so long remained unfulfilled, and also the conviction of their imminent fulfilment. It goes only a little beyond the evidence to say that in every generation between the mid-second century $B C$ and the mid-second century $A D$ Jewish apocalyptists encouraged their readers to hope for the eschatological redemption in the very near future. At the same time there is very little evidence to suggest that during that long period the continued disappointment of that

3. E.g. D. Cullman, Christ and Time (ET, London: SCM, 1951) 86-90; Salvation in History (ET, London: SCM, 1967) 236-47; H. Conzelmann, An Outline of the Theology of the New Testament (ET, London: SCM, 1969) 307-17. It is remarkable that the school of 'Consistent Eschatology', for which the interpretation of Jesus and the early church by reference to Jewish apocalyptic was a methodological principle and which postulated a major crisis of delay in early Christianity, seems not to have asked how Jewish apocalyptic coped with the problem of delay: $c f$. M. Werner, The Formation of Christian Dogma (ET, London: A. \& C. Black, 1957). 
expectation discredited the apocalyptic hope or even diminished the sense of imminence in later generations. The apocalypses of the past were preserved and treasured; and passages whose imminent expectation had clearly not been fulfilled were nevertheless copied and by no means always updated. Each apocalyptist knew that his predecessors had held the time of the End to be at hand, but this knowledge seems to have encouraged rather than discouraged his own sense of eschatological imminence. Clearly the problem of delay was an inescapable problem at the heart of apocalyptic eschatology, but the tension it undoubtedly produced was not a destructive tension. It was a tension which the apocalyptic faith somehow embraced within itself. The problem was felt but it did not lead to doubt.

The question we need to ask, then, is: how did Jewish apocalyptic manage to cope with the problem of delay? The key to this question - and the theme of much of this lecture - is that alongside the theological factors which promoted the imminent expectation there were also theological factors accounting for the fact of delay. These two contrary sets of factors were held in tension in apocalyptic. They were not harmonized to produce a kind of compromise: expectation of the End in the fairly near future but not just yet. The factors promoting imminence and the factors accounting for delay (or even, as we shall see, promoting an expectation of delay) are held in paradoxical tension, with the result that the imminent expectation can be maintained in all its urgency in spite of the continuing delay.

Strobel has shown that many of the apocalyptic references to the delay allude to the text Habakkuk $2: 3$, which seems to have been the locus classicus for reflecting on the problem of delay./4/ 'The vision is yet for the appointed time. It hastens to the end and will not lie. If it tarries, wait for $1 t$, for it will surely come and will not be late.' This text and the history of its interpretation contain the basic apocalyptic 'explanation' of the delay, insofar as it may be called an explanation. It appeals to the omnipotent sovereignty of God, who has determined the time of the End. Even though it is longer in coming

4. Strobel, op. cit. chs. 1 and 2 . 
than the prophecies seem to have suggested, this apparent delay belongs to the purpose of God. It will not be 'late' according to the timescale which God has determined.

Now it cannot be said that this explanation explains very much. The delay remains incomprehensible to men, but is attributed to the inscrutable wisdom of God. But it is important to notice that the effectiveness of this explanation derived not so much from its power as an intellectual explanation, but rather from its quality as an affirmation of faith in God which calls for an appropriate response. Acknowledging the sovereignty of God and the truth of his promises, the apocalyptic bellever is called therefore to wait patiently, persevering in obedience to God's commandments in the meantime. As the Qumran commentary on Habakkuk 2:3 puts 1t: 'Interpreted, this concerns the men of truth who keep the Law, whose hands shall not slacken in the service of the truth when the final age is prolonged. For all the ages of God reach their appointed end as he determines for them in the mysteries of his wisdom. '/5/ Thus the apocalyptic 'solution' to the problem of delay was practical as much as theological. The believer's impatient prayer that God should no longer delay was balanced by the attitude of patient waiting while, in his sovereignty, God did delay. And these two attitudes remained in tension: the apocalyptists maintained both. On the one hand the impatient prayer was met by the assurance that God would bring salvation at the appointed time and therefore with an exhortation to patience; on the other hand the believer's patient waiting was encouraged and supported by the assurance that there would be only a short time to wait and therefore by an exhortation to hope. In this way the tension of imminence and delay was maintained and contained within the apocalyptist's faith.

Essentially this is why the problem of delay did not discredit or destroy the apocalyptic hope. From the beginning apocalyptic faith incorporated the problem of delay. It was a real problem creating a real tension:

5. 10pHab 7:10-12, trans. in G. Vermes, The Dead Sea Scrolls in English (Harmondsworth: Penguin, 1968) 239. 
there is genuine anguish in the apocalyptists' prayers 'Do not delay!' (Dn. 9:19; 2 Baruch 21:25) and 'How long?' (Dn. 12:6; 2 Baruch 21:19). But the tension was held within a structure of religious response whlch was adequate to contain it.

I have admitted that the basic apocalyptic response to the problem of delay - the appeal to the sovereignty of God - provided littie in the way of explanation. Iater we shall see how some apocalyptists, especially in the later period, filled out this explanation with some attempts at more positive understanding of the meaning of the delay. For much of the period when apocalyptic flourished, however, it would seem that the problem of delay was contained mainly by the appeal to the sovereignty of God to balance the urgency of the imminent expectation. It is necessary to ask whether this was theologically legitimate. In other words, it may be that the fact of delay ought to have discredited the apocalyptic hopes, if only it had been squarely faced in the cool light of reason. What I have called the structure of religious response by which

apocalyptic contained the problem may have been no better than a psychological means of maintaining false expectations. History could supply many examples of unfulfilled prophecies which managed to maintain their credibility long after they deserved to do so, often because believers who have staked their lives on such expectations are not easily disillusioned. Is there any reason to put the apocalyptists in a different category?

I believe there is a good reason at least to take the apocalyptic faith very seriously indeed. The problem of delay in apocalyptic is no ordinary problem of unfulfilled prophecy. The problem of delay is the apocalyptic version of the problem of evil. The apocalyptists were vitally concerned with the problems of theodicy, with the demonstration of God's righteousness in the face of the unrighteousness of his world. They explored various possibilities as to the origins of evil and the apportioning of responsibility for evil,/6/ but

6. Cf. the survey in A. L. Thompson, Responsibility for Evil in the Theodicy of IV Ezra (SBL Dissertations Series 29. Missoula, Montana: Scholars Press, 1977) ch. 1 . 
of primary and indispensable significance for the apocalyptic approach to the problem of evil was the expectation of the End, when all wrongs would be righted, all evil eliminated, and God's righteousness therefore vindicated. The great merit of the apocalyptic approach to theodicy was that it refused to justify the present condition of the world by means of an abstract exoneration of God from responsibility for the evils of the present. Only the overcoming of present evil by eschatological righteousness could vindicate God as righteous, and only the hope of such a future triumph of righteousness could make the evils of the present bearable.

Of course, this was no armchair theodicy, but was produced by concrete situations of injustice and oppression in which the apocalyptists lived and suffered: the continued oppression of Israel by the Gentiles, and/ or the sufferings of the righteous remnant of Israel with whom the apocalyptists often identified themselves. It is not always easy for us to appreciate the apocalyptists' concern for righteousness in these situations: the desire for Israel's vindication and her enemies' condemnation can seem to us like mere narrow nationalism, and the apocalyptists' conviction of belonging to the righteous remnant which is unjustly suffering while sinners prosper can seem to us like arrogant self-righteousness. Undoubtedly those defects sometimes mar the apocalypses, but it is important to realize that the genuinely ethical character of the apocalyptic hope is far more dominant. What is at stake in the sufferings of God's people is the righteousness of God, which, as often in the old Testament, means at the same time justice for the oppressed and against the oppressor. It is true that the apocalyptists often fail to see that the problem of evil extends to the sinfulness of the righteous themselves, but they have an agonizingly clear grasp of the problem of innocent suffering. When the problem of theodicy is posed in that form I think we still have much to learn from them. Moreover, the special characteristic of the apocalyptists' grasp of the problem is that, out of their own situation, they were able to see the universal dimensions of the problem of evil, the universal dominance of evil in 'this present evil age', as they came to call the present. This universal challenge to the righteousness of God demanded a universal righting of wrongs, an elimination of evil on a universal, even cosmic, scale. 
I have dwelt on this aspect of apocalyptic because I hope it will enable us to see the real meaning of the problem of eschatological delay. The imminent expectation expresses the extremity of the situation, the intensity of the apocalyptists' perception of the problem of evil, in its sheer contradiction of the righteousness of God. Surely God can no longer tolerate it. Yet he does: there is the problem of delay. What is greatly to the credit of the apocalyptists is that in this dilemma they abandoned neither the righteousness nor the sovereignty of God, which make up the theistic form of the problem of evil. Their belief in the powers of evil was not dualistic: God remained in ultimate control. And so in the face of the delay, they continued to hold that God is righteous - his eschatological righteousness is coming - and that he remains sovereign - the delay belongs to his purpose and the End will come at the time he has appointed. This is the tension of imminence and delay, the tension experienced by the theistic believer who, in a world of injustice, cannot give up his longing for righteousness. Thus we do not, I think, have the right to ask the apocalyptist to explain the delay in any complete sense, because the problem of evil is not susceptible to complete theoretical explanation. The tension which apocalyptic faith contained within itself is the tension which all forms of theism must somehow contain if they take the problem of evil seriously. It is a tension which cannot be resolved by explanation but only by the event of the final victory of God's righteousness.

I conclude, therefore, that the apocalyptists rightly maintained the tension of imminence and delay, and that in some degree that tension must remain a feature of Christian theology. The promise of God's eschatological righteousness presses in upon the present, contradicting the evils of the present, arousing our hopes, motivating us to live towards it. Because the righteousness of God himself is at stake in this expectation it demands immediate fulfilment. That the fulfilment is delayed will always contain a hard core of incomprehensibility: the greatest saints have protested to God against his toleration of evil, and have done so in faith, because of their conviction of his righteousness. But must the delay remain completely incomprehensible? The difficulty of the mere appeal to God's sovereignty is that it is in danger of evacuating the present in which we live of all meaning. The present becomes the 
incomprehensible time in which we can only wait, and it must be admitted that the apocalyptists do sometimes approach this bleakly negative view of the present.

This danger, however, was partially met in the Jewish apocalyptic tradition itself in attempts to find some positive meaning in the delay. Such attempts become particularly evident in the later period of Jewish apocalyptic, espectally after the fall of Jerusalem in $A D 70$, and they have parallels in the Christian literature of the same period. I think this fact must correspond to a certain intensification of the problem of delay in late first-century Judaism. This was not due to the mere continuing lapse of time; it is a mistake to suppose the problem of delay necessarily increases the longer the delay. The problem is intensified not by the mere lapse of time, but by the focusing of expectation on specific dates or events which fail to provide the expected fulfilment. In the case of Jewish apocalyptic, the Jewish wars of AD 66-70 and 132-135 were disappointments of the most extreme kind, for so far from being the onset of eschatological salvation, they proved to be unprecedented contradictions of all the apocalyptists had hoped for. Consequently the apocalyptic writers of the late first century are engaged in a fresh and agonizing exploration of the issues of eschatological theodicy. The imminent expectation seems if anything to be heightened, but it seems to require that on the other hand some meaning be found in the interval of delay.

So we will turn to four specific examples of the problem of delay in the late first century, two Jewish examples and then for comparison two Christian examples which are relatively close to the Jewish discussion. In all of them we shall be looking espectally for attempts to understand the delay.

\section{FOUR EXAMPLES FROM THE LATE FIRST CENTURY AD}

\section{(a) A Rabbinic Debate}

There is a well-known rabbinic tradition of a debate 
about the delay of eschatological redemption/7/ between $R$. Eliezer $b$. Hyrcanus and $R$. Joshua b. Hananiah./8/ If authentic, this debate will date from the late first century $A D$. Unfortunately its authenticity cannot be assumed as uncritically as it has generally been./9/ Neusner, in his classification of the traditions of $R$. Eliezer according to the reliability of the attestation, places this tradition in his least well attested category, 'The Poor Traditions':/10/ this means not only that the attestation of the tradition is late, but also that its content is largely unrelated to earlier traditions. Traditions in this category are not thereby shown to be inauthentic, but their authenticity is very difficult to establish with any degree of certainty. There are, however, some things to be said in favour of our tradition: (1) It belongs to a group of traditions which together form a coherent set of opinions on issues which were certainly matters of concern to the rabbis in the period immediately after $A D$ 70. In other words, they are historically appropriate to Ellezer's historical situation, and they are mutually consistent./11/ (2) Neusner also concludes that this group of traditions represent in substance what we should have expected Eliezer to have thought about these topics, on the basis of the best attested sayings of Eliezer./12/ (3) Furthermore, there is a passage in the Apocalypse of Ezra (c. AD 100) which proves that the contrasting views of $R$. Eliezer and $R$. Joshua, as represented in our tradition, were held and debated during their lifetimes: in 4 Ezra 4:38-42, Ezra puts forward as. a suggestion the attitude to the problem of eschatological delay which our tradition attributes to R. Eliezer, while the angel's reply maintains the position attributed to $R$. Joshua. Thus, even if we

7. For the sake of simplicity, in this and the following section I am ignoring the problems of the distinction between expectation of the messianic kingdom and expectation of the age to come. They do not greatly affect our topic.

8. Midrash Tanhuma Behuqotai 5; y Tacan. 1:1; b Sanh. 97b-98a. The texts are given in translation in $\mathrm{J}$. Neusner, Eliezer ben Hyrcanus (Leiden: E. J. Brill, 1973) I 477-79.

9. E.g. Strobel, op. cit. 23-26.

10. Neusner, op. cit. II 235, no. 57.

11. Ibid. II 417-21.

12. Ibid. II 421. 
cannot be quite sure that R. Eliezer and R. Joshua themselves held the opinions attributed to them, we can at least be sure that those opinions were debated in the late first century.

In the briefest version of the debate the issue is succinctly stated as follows:
R. Eltezer says, 'If Israel repents, they will be redeemed'.
R. Joshua says, 'Whether or not they repent, when the end comes, they will forthwith be redeemed, as it is said, "I the Lord in its time will hasten it" (Is. $60: 22) .1 / 13 /$

R. Joshua maintains the traditional apocalyptic appeal to the sovereignty of God, who has determined the time of the End. When the appointed time arrives, the eschatological redemption will come as God's sovereign grace to Israel, in no way dependent on Israel's preparation. R. Eliezer, on the other hand, makes the coming of redemption conditional on Israel's repentance.

The idea of Israel's repentance before the End was not new,/14/ but the view that it is a condition for the arrival of redemption is at least rare in the earlier

13. Midrash Tanhuma Behuqotai 5 (Neusner, op. cit. I 479). The use of Is. 60:22 with reference to this issue is well attested for this period: Ecclus. 26:8; 2 Baruch 20:1f; 54:1; 83:1; Ep. of Barnabas $4: 3$; cf. Ps-Philo, Lib. Ant. Bib. 19:13; 2 Pet. 3:12. Cf. further rabbinic references in strobel, op. cit. 92 n. 6.

14. Cf. Testament of Moses 1:18. It is presupposed in the message of John the Baptist, but his teaching in Mt. 3:7-10 par. Lk. 3:7-9 seems to run counter to any suggestion that Israel's redemption was a necessary condition for the coming of the Kingdom. Similarly Lk. 13:6-9 embodles the idea of delay in order to give time for repentance, but explicitly not until repentance. 
literature,/15/ though it subsequently became a common rabbinic view. It seems probable that Eliezer's saying represents a reaction to the disaster of $A D 70$, when hopes of redemption were dashed and Israel experienced instead a catastrophe which could only be interpreted as divine punishment. The conclusion must be that Israel was unworthy of redemption. Only when Israel repented would redemption come.

Eliezer's position could mean that the divinely appointed date for the End had actually been postponed because of Israel's sins,/16/ as some later Rabbis certainly held. /17/ Alternatively it could mean that there is no such thing as a fixed date for the End,/18/ or, finally, it could mean that Israel's repentance is itself part of God's predetermined plan. This is the view suggested by a longer version of the debate:

R. Eliezer says, 'If Israel does not repent, they will never be redeemed....'.

R. Joshua said to him, 'If Israel stands and does not repent, do you say they will never be saved?'.

R. Eliezer said to him, 'The Holy One, blessed be he, will raise up over them a king as harsh as Haman, and forthwith they will repent and be redeemed'./19/

In other words redemption cannot be indefinitely postponed by Israel's failure to repent, because God himself will stir Israel to repentance.

15. But cf. Testament of Dan 6:4; Acts 13:19-21.

16. This is how Eliezer is understood by strobel, op. cit. 23-26.

17. b Sanh. 97b; b 'Abodah Zarah 9a.

18. This is how Eliezer is understood by E. E. Urbach, The Sages: Their Concepts and Beliefs (ET, Jerusalem: Magnes Press, 1975) I 669.

19. y Tacan. 1:1 (Neusner, op. cit. I 477). I follow Neusner (I 479, cf. II 418) in preferring this version to that in $b$ Sanh. $97 b$, which attributes the saying about the cruel king like Haman to $R$. Joshua. (Urbach, op. cit. I 669f., II $996 \mathrm{n} .63$, prefers the latter.) Neusner, op. cit. II 419f, also finds evidence in Pesiqta Rabbati 23:1, that Eliezer did believe in a fixed date at which redemption must come. 
The importance of this debate is that R. Eliezer's view is an attempt to understand the delay. The meaning of the delay is not totally hidden in God's mysterious sovereign purpose. It is the time in which God graciously waits for his people to repent and chastises them until they repent.

\section{(b) The Apocalypse of Baruch}

The Apocalypse of Baruch dates from the late first or early second century $A D$. The pseudonym Baruch and the historical setting immediately following the fall of Jerusalem in $586 \mathrm{BC}$ are transparent vehicles for the author's own reactions to the tragedy of $\mathrm{AD} 70$.

The note of imminent expectation pervades the book (20: 1f,6; 23:7; 48:39; 54:17; 82:2, 83:1; cf. 48:32), most memorably expressed in the often-quoted lines:

The youth of the world is past,

the strength of creation is already exhausted.

The advent of the times is very close,

yea, they have passed by.

The pitcher is near to the well,

and the ship to the port.

The course of the journey is reaching its destination at the city,

and life approaches its end (85:10)./20/

The events of $A D 70$ have not dampened but inflamed the expectation of redemption, but it is clear that the delay, while Israel is humiliated and the Gentiles triumph, is an agonizing problem, especially as Baruch sees God's own honour at stake in the fate of his people $(5: 1 ; 21: 21)$. The problem of delay is focussed in Baruch's question, 'How long will these things endure for us?' (81:3; cf. 21:19), and his prayer that God may

20. Quotations from 2 Baruch are adapted from the translation by R. H. Charles (in R. H. Charles and W. O. E. Oesterley, The Apocalypse of Baruch (London: SPCK, 1917)), with reference to the French translation in P. Bogaert, Apocalypse de Baruch (Sources Chrétiennes 144. Paris: Éditions du Cerf, 1969) I 463-528. 
'now, quickly, show thy glory, and do not delay the fulfilment of thy promise' (21:25).

Alongside the imminent expectation, Baruch recognizes theological factors which account for the delay. First among these is the traditional appeal to the divine sovereignty. Baruch has a strong sense of the qualitative difference between God and man, the majesty and sovereignty of God over against the dependence and frailty of man (14:8-11; 21:4-10; 48:2-17; 54:1-13). One aspect of this is the eternity of $\operatorname{God}(21: 10 ; 48: 13)$ contrasted with the transitoriness of man (14:10f; 48: 12). Unlike man, who cannot even foresee the outcome of his own brief life, God surveys the whole course of the world and is sovereign over all events, determining their times $(48: 2 f ; 54: I ; 56: 2 f)$. Consequently only God knows in advance the time of the End which he has appointed $(21: 8 ; 48: 3 ; 54: 1)$. Baruch's repeated use of the phrase 'in its time' $(5: 2 ; 12: 4 ; 13: 5 ; 20: 2 ; 51: 7 ; 54: 1 ;$ cf. 42: 8) stresses that the End will come only at the time which the eternal sovereign God has appointed. This theme therefore provides a certain counterbalance to the urgency of the imminent expectation.

A minor attempt to fill out this appeal to the divine sovereignty over the times is the idea that God has determined a fixed number of people to be born into this world, so that the End cannot come until that number is complete $(23: 2-5)$. (A similar idea, of a predetermined number of the righteous, is found in 4 Ezra $4: 36$. ) This scarcely constitutes an explanation of the delay: it simply appeals again to the inscrutable divine decree. $/ 21 /$

Baruch, however, has something more substantial to contribute to the understanding of delay. I observed earlier that the imminent expectation in apocalyptic is connected with the apocalyptic perception of the character of God, in particular his righteousness. It is the contradiction between the righteousness of God and

21. Cf. Ezra's (unanswered) queries in 4 Ezra 5:43-45: why could not all the predetermined number of men have lived as a single generation? 
the unrighteousness of present conditions which fires the expectation of God's immediate coming in judgment. It is therefore of the greatest interest that Baruch's understanding of the delay is also related to the character of God, in this case to his longsuffering (patience, forbearance). As Baruch himself is reminded by the angel (59:6), this quality belongs to the central old Testament revelation of God's character, to Moses on Mount Sinai: 'The Lord, the Lord, a God merciful and gracious, slow to anger, and abounding in steadfast love and faithfulness ...' (Ex. 34:6) : the description of God to which the old Testament frequently refers (Nu. 14:18; Pss. 86:15; 103:8; Joel 2:13; Jon. 4:2; Wisdom 15:1; cf. CD 2:4). In Baruch's words, Moses was shown 'the restraint of wrath and the abundance of longsuffering' $(59: 6) . / 22 /$ God's longsuffering is that quality by which he bears with sinners, holds back his wrath, refrains from intervening in judgment as soon as the sinner's deeds deserve it, though not indefinitely./23/ As Baruch correctly sees, it is this quality of God which accounts for the whole history of this sinful world: 'the longsuffering of the Most High, which has been throughout all generations, who has been longsuffering towards all who are born, sinners and righteous' $(24: 2) \cdot / 24 /$

Baruch's use of this theme is unlikely to be original; his references to it are too casual (12:4; 21:20f; 24:2; $48: 29$; 59:6; 85:8). The related and nearly contemporary Apocalypse of Ezra also employs the theme of God's patience $(3: 30 ; 7: 33,74 ; c f .9: 21)$, and includes it in a formal meditation on the character of God according to Exodus 34:6f (7:132-139)./25/ Evidently the apocalyptic

22. Baruch refers to the other characteristics of God according to Ex. 34:6 in 77:7 (merciful, gracious, faithful) and 75:5 (merciful, gracious).

23. Note Strobel's remark (op. cit. 31): 'der für unsere Begriffe anscheinend nur psychologische Begriff der "Langmut" im hebräischen Sprachgebrauch einen ausgesprochen chronologischen Bedeutungsgehalt hat' (my italics).

24. Like Paul (Rom. 2:4), Baruch can also sometimes connect this slightly negative quality of longsuffering with the more positive quality of kindness (48:29; cf. $13: 12$; $82: 9$ ).

25. On this passage, see Thompson, op. cit. 202f, 301-3. 
tradition had already related its eschatological concerns to the classic features of the character of God, and seen not only God's sovereignty but also his longsuffering in the delay.

The attribution of delay to God's patience does not always enable Baruch to take a positive view of it. In his grief over the fall of Jerusalem and the contrasting prosperity of her enemies, Baruch, like Jeremiah before him (Je. 15:15; cf. Jon. 4:2), reproaches God for his patience, for restraining his wrath while his people's enemies triumph (11:3; cf. Is. 64:12; 4 Ezra $3: 30)$. And in his impassioned plea for God to hasten the judgment, Baruch prays:

How long will those who transgress in this world be polluted with their great wickedness? Command them in mercy, and accomplish what thou saidst thou wouldst bring, that thy might may be known to those who think that thy longsuffering is weakness (21:19f).

It is worth noticing in that passage how God's mercy is opposed to his longsuffering. His mercy here means his mercy to the righteous who suffer; the coming of God in judgment is at the same time mercy to the righteous and condemnation to the wicked $(82: 2) . / 26 /$ In other words Baruch asks that God in his mercy to the righteous should put an end to his longsuffering towards the wicked. He is aware, then, that his plea that God should no longer delay, while it is founded, as prayer must be, on the character and promises of God, appeals only to one aspect of God's dealings with men against another. Baruch knows that if the imminence of the judgment is demanded by God's mercy to the righteous (which goes hand in hand with his judgment on the wicked), the delay in judgment is also founded on the character of God, on his longsuffering, which restrains his wrath towards the wicked (but therefore also delays his mercy to the righteous).

26. Baruch holds the common Jewish view of this period, that God will show mercy to the righteous and strict justice to the wicked; $C f$. E. P. Sanders, Paul and Palestinian Judaism (London: SCM, 1977) 421. 
Baruch's attitude to God's forbearance varies according to the aspect of the fall of Jerusalem which he considers. When he laments the humiliation of Israel at the hands of her godless enemies, God's tolerance of the situation seems incomprehensible to Baruch. When, however, he considers God's patience with Israel it becomes a more positive concept $(85: 8)$. For Baruch interprets the fall of Jerusalem as God's chastisement of his people for their sins $(1: 5 ; 4: 1 ; 13: 10 ; 78: 6 ; 79: 2)$ : 'They were chastened then so that they might be forgiven' (13:10). Although the fall of Jerusalem was God's judgment on Israel, it was a judgment which manifested God's patience with them. It was a warning judgment, designed to bring them to repentance, whereas when the final judgment comes there will no longer be any time left for repentance $(85: 12)$. In this way the delay gains the positive aspect of a respite, in which God's people, who would perish if the final judgment came sooner, are graciously granted the opportunity of repentance./27/ In the paraenetic sections of the book Baruch urges this lesson on his readers $(44: 2-15 ; 46: 5 f$; $77: 2-10 ; 78: 3-7$; $83: 1-8$; 84:1 - 85:15).

Finally we must notice the initially puzzling statement in which God says: 'Therefore have I now taken away Zion, so that I may hasten to visit the world in its time' (20:2) ./28/ The meaning of this verse must be that because cod wills the repentance of his people before the End, he has stirred them to repentance by destroying Jerusalem. The fall of Jerusalem brings the End nearer, in that it brings about a precondition of the End, the repentance of Israel. The thought is similar to $R$. Eliezer's saying about the cruel king like Haman. Here it is even clearer than in R. Eliezer's case that there is no contradiction between this thought and the idea, which Baruch stresses, that the End will come at the time God has determined. That God will 'hasten to visit the world in its time' does not mean that he will advance the date of the End, but that, now Jerusalem has fallen, the appointed time of the End is fast approaching.

27. Baruch's hints that the delay can also benefit Gentiles are less explicit, but cf. 1:4; 41:4; 42:5.

28. This verse is dependent on Is. $60: 22$; cf. n. 13 above. 
The present time of delay retains in the Apocalypse of Baruch a predominantly negative character: Baruch's expressions of the miseries and worthlessness of this life have often been cited as prime examples of apocalyptic pessimism./29/ In the shadow of the tragedy of $A D 70$ this aspect is hardly surprising. More remarkable, for our purposes, are the traces of a positive theological understanding of the delay in terms of God's longsuffering and his desire for his people's repentance. Here Baruch fills out the reported sayings of R. Eliezer./30/ The urgency of the imminent expectation is not diminished by this recognition of the positive character of the delay: the two are held in tension.

\section{(c) 2 Peter 3}

2 Peter 3 contains the most explicit treatment of the delay of the parousia in the New Testament. It is also, as we shall see, the most thoroughly Jewish treatment, reproducing exactly the arguments we have been studying in the Jewish literature. In fact the passage 3:5-13 contains nothing which could not have been written by a non-Christian Jewish writer, except perhaps the use of the simile of the thief, derived from Jesus' parable, in verse 10. It is possible that the author is closely dependent on a Jewish apocalyptic writing in this chapter, just as he depends on the epistle of Jude in chapter $2 . / 31 /$

29. 21:13f; 83:10-21; but cf: 52:6: 'Rejolce in the sufferings which you now endure.'

30. Strobel, op. cit. 32f, thinks that Baruch agrees with R. Joshua rather than $R$. Eliezer, because he holds that R. Eliezer thought the date of the End was postponed on account of Israel's sins, while Baruch held to God's unconditional determination of the End.

31. D. von Allmen, 'L'apocalyptique juive et le retard de la parousie en II Pierre 3:1-13' Revue de Thélogie et de Philosophie 16 (1966) 255-74, attempts to identify specific verses as quoted from a Jewish apocalypse, but, in view of the way he uses Jude, it is unlikely that the author of 2 Peter would quote without adaptation. It is possible that he is using the apocryphal writing quoted in 1 clement 23:3f and 2 clement 11:2f. 
The problem of delay has been raised by false teachers, who so far as we can tell from the letter combined eschatological scepticism with ethical libertinism (ch. 2), apparently supporting the latter by appeal to Paul's teaching on freedom from the Law $(2: 19 ; 3: 15)$. Whether, as has often been thought, both these features were connected with a Gnostic or proto-Gnostic form of overrealized eschatology $/ 32 /$ is less certain, since there is no clear hint of this in 2 Peter, but it is certainly a real possibility./33/

The allegation of the 'scoffers' that the delay of the parousia disproves the expectation of the parousia is met in verses 8 and 9, with what I take to be two distinct arguments. The first reads: 'But do not ignore this one fact, beloved, that one day before the Lord is as a thousand years, and a thousand years as one day.' Precisely what this argument is intended to prove is a matter of debate among the exegetes, who divide into two schools: (1) those who interpret the verse according to parallels in contemporary Jewish and Christian literature, and conclude that it is not intended to meet

32. E.g. C. H. Talbert, 'II Peter and the Delay of the Parousia' Vigiliae Christianae 20 (1966) 137-45, who holds that their realized eschatology was the real basis of their denial of the parousia: 'it seems that their question about the delay of the parousia, just as their appeal to the stability of the universe, is but an argument used to justify a position held on other grounds' (p. 143). Cf. also E. Käsemann, Essays on New Testament Themes (ET, London: SCM, 1964) 171.

33. In parallel passages where the reality of future eschatology is defended against over-realized eschatology, it is the reality of future resurrection which is usually given special attention (1 Cor. 15; 1 clement 23-26; 2 clement 9-12; '3 Corinthians' 3 : 24-32), but it is quite possible that the author of 2 Peter deliberately preferred to deal with the question of future judgment because for him the ethical implications of traditional eschatology were paramount and he clearly regarded the eschatology of the 'scoffers' as an excuse for their immoral behaviour (cf. also Polycarp, Philippians 7). 
the problem of delay;/34/ (2) those who interpret the verse as an answer to the problem of delay, and conclude that the author has here produced an original argument which has no known precedent or parallel in the literature.

The first school point to the many rabbinic and secondcentury christian texts in which an eschatological chronology is based on the formula 'A day of the Lord is a thousand years'. This seems to have been a standard exegetical rule, derived from Psalm 90:4 ('a thousand years in thy sight are but as yesterday when it is past'), but existing as an independent formulation. The procedure is to quote a biblical text in which the word 'day' occurs; then the rule 'A day of the Lord is a thousand years' is cited, with or without a further quotation of Psalm 90:4 to support it; the conclusion is therefore that where the text says 'day' it means, in human terms, a thousand years. The rule was sometimes applied to the creation narrative, in order to yield the notion that the history of the world is to last six thousand years, six 'days' of a thousand years each, followed by a millennial Sabbath: this calculation lies behind the widespread millenarianism of the second century./35/ Or, similarly, the rule could be applizd to texts which were thought to mention the day or days of the Messiah (Is. 63:4; Ps. 90:15): in another tradition of debate between R. Eliezer and R. Joshua, R. Eliezer concluded that the messianic kingdom would last a thousand years, but R. Joshua argued that 'days' (plural, Ps. 90:15) implies two thousand years./36/ The application of the rule was not always to eschatological

34. F. Spitta, Der zweite Brief des Petrus und der Brief des Judas (Halle: Buchhandlung des Waisenhauses, 1885) 251-57; Strobel, op. cit. 93f; von Allmen, art. cit. 262.

35. Ep. of Barnabas 15:4; Irenaeus, $A d v$. Haer. 5:28:3; cf. b Sanh. 97a.

36. Midrash on Psalms on Ps. 90:4; Pesiqta Rabbati 1:7 (where R. Eliezer is the later R. Eliezer b. R. Jose the Galilean). There are further calculations on a similar basis in Pesiqta Rabbati 1:7; b Sanh. 99b; Justin, Dial. 81 . 
matters:/37/ it was also very commonly used to interpret Genesis 2:17 in accordance with the length of Adam's life./38/ But all of these instances are chronological calculations: the point is not, as originally in Psalm 90:4, to contrast God's everlasting life with the transience of human life, but simply to yield the chronological information that one of God's days, when Scripture mentions them, is equal to a thousand of our years.

If these parallels are to govern the interpretation of 2 Peter $3: 8$, then the verse means that the 'day of judgment', mentioned in verse 7 , will last a thousand years. Verse 8 is then not a contribution to the debate about the delay, but an explanation of the eschatological expectation set out in verse 7 .

Now it is true that 2 Peter 3:8 appears to cite the current exegetical rule in the first half of the saying ('one day before the Lord is as a thousand years')/39/ and then, in the second half, to back it up by citing Psalm 90:4. It is also a sound hermeneutical principle to expect a writer to follow the exegetical methods of his contemporaries./40/ In this case, however, the resulting exegesis of verse 8 is very hard to sustain in context: (1) The introductory words ('But do not ignore

37. As von Allmen, art. cit. $262 \mathrm{n} .1$; cf. Strobel, op. cit. 93.

38. Jubilees 4:30 (the earliest example of this use of Ps. 90:4); Gen. R. 19:8; 22:1; Midrash on Psalms on Ps. 25:6; Justin, Dial. 81; Irenaeus, $A d v$. Haer. 5: 23:2; Pirqe de R. Eliezer 18. Gen. R. 8:2 uses the rule to prove from $\mathrm{Pr}$. 8:30 that the Torah preceded the creation of the world by 2000 years.

39. This is closer to Ps. 90:4 than the usual formulation of the rule, but, for $\pi \alpha \rho \alpha$ Kupíy, see $E p$. of Barnabas 15:4 ( $\left.\pi \alpha \rho^{\circ} \alpha \cup \dot{\tau} \tau\right)$, and, for $\omega S$, see Justin, Dial. 81; Irenaeus, Adv. Haer. 5:23:2; $5: 28: 3$.

40. Von Allmen, art. cit. 262 n. 1. 
this one fact, beloved') formally signal a fresh line of thought, not an explanatory footnote to verse 7 . (2) If verse 8 means that the day of judgment will last a thousand years, it contributes nothing to the argument against the 'scoffers'. It is hard to believe that in such a brief section the author would have allowed himself this entirely redundant comment. (3) There is actually no parallel to the idea that the day of judgment would last a thousand years, and it is difficult to see how it could fit into the eschatology of 2 Peter 3.

Must we then conclude, with the majority of exegetes, that the author's use of Psalm 90:4 in this verse is entirely unprecedented?/41/ Not at all, for there are in fact two relevant Jewish parallels which, so far as I can tell, the commentators have not noticed, presumably because Strack and Billerbeck missed them.

The first is a piece of rabbinic exegesis which belongs to the tradition of apocalyptic interpretation of the revelation to Abraham in Genesis 15. It is ascribed to the early second-century Rabbi Eleazar b. Azariah, and although the attestation is late, the fact that it seems closely related to the traditions embodied in the Apocalypse of Abraham/42/ perhaps permits us to consider it in this context. From the text of Genesis 15 it is

41. E.g. J. N. D. Kelly, A commentary on the Epistles of Peter and of Jude (London: A. \& C. Black, 1969) 362.

42. Apocalypse of Abraham 28-30: the text is partly corrupt and in ch. 29 has suffered Christian interpolation, so that it is difficult to be sure of the chronological reckonings. It seems that the whole of this 'age of ungodliness' is reckoned as one day of twelve hours (perhaps on the basis on Gen. 15:11), and perhaps each hour lasts 400 years (as in ch. 32) rather than 100 years (as the present text of ch. 28 seems to indicate). In any case, the general approach to Gen. 15 is similar to that in Pirqe de $R$. Eliezer 28, and it is relevant that $\mathrm{L}$. Hartman, 'The Functions of Some So-Called Apocalyptic Timetables', NTS 22 (1975-6) 10, considers that the message of the 'timetable' in the Apocalypse of Abraham 'is not a calculation of the end, but rather an attempt to solve the moral and religious problem posed by the situation of the faithful'. 
deduced that the period during which Abraham (according to 15:11) drove away the birds of prey from the sacrificial carcasses was a day, from sunrise to sunset. The birds of prey are taken to represent the Gentile oppressors of Israel during the period of the four kingdoms. Therefore, R. Eleazar says, 'From this incident thou mayest learn that the rule of these four kingdoms will only last one day according to the day of the Holy one, blessed be he'./43/ The reference to 'the day of the Holy one' must be to the maxim 'A day of the Lord is a thousand years'.

The relevance of this text is that, unlike the other rabbinic texts already mentioned, it does relate to the delay of the End, for in Jewish apocalyptic the period of the four kingdoms is precisely the period of delay. Moreover, I doubt whether the exegesis is primarily intended as a chronological calculation,/44/ again unlike the other texts. The point is that the rule of the four kingdoms 'will only last one day', i.e. that although for oppressed Israel the time seems very long, from God's eternal perspective it is a very brief period. This reflection therefore has the function of

43. Pirqe de R. Eliezer 28: translation from G. Friedlander, Pirḳ̂e de Rabbi Eliezer (New York: Hermon Press, 19652) 200. I owe my knowledge of this text to P. Bogaert, op. cit. II 88, who quotes from the same tradition in Yalquț Shim 'oni 76.

44. If the text were interpreted chronologically, then perhaps it would be plausible to suggest a date of origin for the tradition when the end of a period of one thousand years from $586 \mathrm{BC}$ was approaching. But even in the case of texts which appear to be more interested in chronology, such calculations of date cannot be trusted: if 4 Ezra 10:45f; 14:11f were taken literally and according to modern chronology, the End would have been far distant In the future when the book was written; similarly Ps-Philo, Lib. Ant. Bib. 19:15 (accepting the very plausible emendation proposed by $M$. Wadsworth, 'The Death of Moses and the Riddle of the End of Time in Pseudo-Philo' JJS 28 (1977) 14f). 
consolation for Israel, in that it relativizes the importance of the period of Gentile domination. It thus provides a parallel to the thought of 2 Peter 3:8, which is surely that those who complain of the delay have got it out of perspective: in the perspective of eternity it is only a short time.

With the second parallel we are on chronologically safer ground, for it comes from the Apocalypse of Baruch. In a passage clearly inspired by Psalm 90, Baruch reflects on the contrast between the transience of man and the eternity of God:

For in a little time are we born, and in a little time do we return. But with thee the hours are as the ages, and the days are as the generations (2 Baruch 48:12f).

At least this text proves that it was possible for a contemporary of the author of 2 Peter to read Psalm 90:4 in its original sense of a contrast between God's endless existence and man's brief span of life. In its immediate context in 2 Baruch it is not directly related to the problem of delay, but it is an instance of Baruch's frequent theme of God's sovereignty over the times, which, as we have seen, is one of the themes which serves to balance the theme of eschatological imminence.

These two parallels seem to me to illuminate the meaning of 2 Peter 3:8. This verse is not, as Käsemann complains, 'a philosophical speculation about the being of God, to which a different conception of time is made to apply from that which applies to us'./46/ It does not mean that God's perception of time is so utterly unrelated to

45. As R. H. Charles, The Apocalypse of Baruch (London: A. \& C. Black, 1896) 75, ad loc., notes, we should have expected 'the ages are as the hours and the generations are as the days'; perhaps this should caution us against seeing too much detailed significance in the two halves of the saying in 2 Pet. $3: 8$.

46. Op. cit. 194. 
ours that the very idea of delay becomes quite meaningless and nothing can any longer be said about the time until the parousia. Rather the verse contrasts man man's transience with God's everlastingness, the limited perspective of man whose expectations tend to be bounded by his own brief lifetime with the perspective of the eternal God who surveys the whole of history. The reason why the imminent expectation of the apocalyptist tends to mean to him the expectation of the End within his own lifetime is, partly at least, this human limitation: he is impatient to see the redemption himself. The eternal God is free from that particular impatience./47/ The implication is not that the believer should discard the imminent expectation,/48/ but that he must set against it the consideration that the delay which seems so lengthy to him may not be so significant within that total perspective on the total course of history which God commands.

In 2 Peter 3:9 the author offers his positive understanding of the delay: 'The Lord is not slow about his promise, as some count slowness, but is forbearing toward you, not wishing that any should perish, but that all should reach repentance.' I hope that adequate comment on this verse has already been provided by the whole of our study of the Jewish apocalyptic material. The problem of delay is here met in a way which had become standard in the Jewish thinking of the time:/49/

47. Cf. Augustine's saying, quoted by C. Bigg, A Critical and Exegetical Commentary on the Epistles of St Peter and St Jude (Edinburgh: T. \& T. Clark, 1901) 295, and repeated by M. Green, The Second Epistle General of Peter and the General Epistle of Jude (London: IVP, 1968) 134, that God is patiens quia eternus.

48. T. Fornberg, An Early Church in a Pluralistic Society (Coniectanea Biblica: NT Series 9. Lund: Gleerup, 1977) 68 thinks that ' 2 pet $3: 8$ is the earliest example of the explicit abandonment by an orthodox Christian writer of the expectation of a speedy Parousia'.

49. Fornberg, ibid. 71, who wishes to stress the Hellenistic and non-Jewish character of 2 Peter, neglects the Jewish parallels to $3: 9$ in favour of the parallel in Plutarch, De sera numinis vindicata. But the whole context makes the Jewish parallels the relevant ones. 
in fact this verse is a succinct statement of the ideas about the delay which we have traced in Jewish apocalyptic. There is first of all the appeal to God's sovereignty: he is not late in fulfilling his promise (this point is made by means of the standard reference to Hab. $2: 3$ ) $; / 50 /$ the delay belongs to his purpose. Then the positive meaning of the delay is explained as R. Eliezer and the Apocalypse of Baruch explained it. God restrains his anger in order to give his people (now Christians rather than Jews) opportunity to repent./51/

The author of 2 Peter, then, met the problem of delay as posed by the 'scoffers' from the resources of the Jewish apocalyptic tradition. His arguments were not novel arguments hastily contrived to meet the unexpected crisis of delay. They were arguments familiar in contemporary Jewish circles where the problem of delay was part and parcel of the apocalyptic tradition. Like the author of the Apocalypse of Baruch, the author of 2 Peter recognized that alongside the theological factors which make for imminence must be set theological factors which account for delay. Against the apocalyptists' longing for

50. Cf. Ecclus. 35:18, but there the emphasis is very different.

51. The $\pi$ óvias must mean, initially at least, all the readers. The Christian mission is not here in view: contra A. L. Moore, The Parousia in the New Testament (Supplements to Novum Testamentum 13. Leiden: E. J. Brill, 1966) 154.

The further comment, in 3:12, that Christians by living holy lives may 'hasten' the coming of the End is the obverse of $3: 9$. The reference to Is. 60:12 was traditional (see n. 13 above), though it is usually God who is said to hasten the time of the End. There are, however, rabbinic parallels, such as the saying of $R$. Judah, 'Great is charity, for it brings redemption nearer' ( $b$ Baba Batra 10a), and the saying of $R$. Jose the Galilean, 'Great is repentance, for it brings redemption nearer' (b Yoma 86b).

As we have already noticed in the case of $R$. Eliezer and the Apocalypse of Baruch, this idea need not contradict the view that God has appointed the time cf the End; it only means that God's sovereign determination takes human affairs into account. 
eschatological righteousness, which this writer clearly shared $(3: 13)$, must be set the patience of God who characteristically holds back from condemning the sinner while he may still repent. The believer must hold the two sides of the matter in tension. Only God from the perspective of eternity knows the temporal point at which they meet, where the tension will be resolved in the event of the End. The problem of delay is thus contained within the expectation, as it always had been in the Jewish tradition.

\section{(d) The Apocalypse of John}

Finally, we turn to the Apocalypse of John, which, rooted as it is in the apocalyptic tradition, employs the traditional Jewish approaches to the problem of delay, but also, being a deeply Christian apocalypse, employs them with far more creative Christian reinterpretation than we have found in 2 peter.

By now it should come as no surprise to learn that the imminent expectation and the delay of the parousia both feature in Revelation. The note of imminence is more obvious, owing to the emphasis it receives in the opening and closing sections of the book $(1: 1,3 ; 22: 6,7,10,12,20)$. The motif of delay is somewhat less evident to us, but would have been clear enough to John's readers: it can be found principally in the section chapters 6-11.

We should notice first how the imminent expectation receives a thoroughly Christian character: it is the parousia of Jesus Christ which is expected. Not simply the End, but Jesus, is coming soon $(2: 16 ; 3: 11 ; 22: 7,12$, 20; cf. $1: 7 ; 3: 3$; 16:15). Moreover, this Jesus has already won the eschatological victory over evil $13: 21$; $5: 5 ; 12: 7-11)$; as the passover Lamb he has already accomplished the new Exodus of the End-time (5:6-10; cf. 15:3); he already holds the keys of death, and rules the world from his Father's throne (1:18; $3: 21 ; 1: 5)$.

It has frequently been said that, by comparison with Jewish apocalyptic, the problem of eschatological delay was less acute for the early church because of the element of realized eschatology in Christian thinking. No longer was the future expectation paramount, because in the death and resurrection of Jesus in the past God had 
already accomplished the decisive eschatological act./52/ There is truth in this argument - and, as we shall see, it is this past act of God in Christ which gives the present time of delay its positive meaning in Revelation - but it should also be noticed that the tension of 'already' and 'not yet' in early Christianity also functioned to heighten the sense of eschatological imminence. For if the victory over evil has already been won, it seems even more necessary that the actual eradication of evil from the world should follow very soon. The powers of evil at work in the world loom large in the imagery of Revelation: the problems of theodicy which they pose are, in one sense, not alleviated but intensified by the faith that Christ has already conquered them. Thus the characteristic tension of imminence and delay in Jewish apocalyptic seems to be, if anything, sharpened by the 'already' of Christian faith, since it contributes to both sides of the tension.

The message of Revelation is conveyed as much by literary impact as by conventional theological statement, and this is true of the motif of delay in chapters 6-11. In those chapters John portrays the movement from Christ's victory on the cross towards the fulfilment of that vict ory at the parousia, and he structures that movement in the series of sevens: the seven seals, the seven trumpets, and the further series of seven bowls which follows in chapter 16. In chapter 5 the reader has heard of the victory of the Lamb, who is declared worthy to open the scroll, i.e. to release into the world God's purpose of establishing his Kingdom. The Lamb's victory on the cross is the fundamental achievement of that purpose; all that remains is its outworking in world history. So John's original readers would move into chapter 6 full of expectancy: a rapid series of apocalyptic judgments would quickly crush all opposition and inaugurate the Kingdom. This expectancy, however, is deliberately frustrated throughout chapters 6-11. The impressive quartet of horsemen who are released into history when the lamb opens the first four seals turn out $(6: 8)$ to be disappointingly moderate judgments, affecting only a quarter of the earth. The readers' sense of disappointment will correspond to the cry of the martyrs, 'How

52. Cf. Cullmann, Christ and Time, 86-90, though Cullmann does acknowledge that the 'already' of primitive Christianity did intensify the eschatological expectation. 
long?', at the opening of the fifth seal (6:10). With the sixth seal, however, expectation will mount again: the familiar apocalyptic imagery heralds the actual arrival of the day of judgment. But again John holds his readers in suspense, inserting a long parenthesis (ch. 7) before the final, seventh seal.

The series of trumpets follow a similar pattern. The judgments are now intensified, but they are still limited, this time affecting a third of the earth and its inhabitants. Instead of accomplishing a swift annihilation of the enemies of God, it becomes clear that these judgments are preliminary warning judgments, designed, in the patience of God, to give men the opportunity of repentance. Following the sixth trumpet, however, we are told that these judgments have not brought men to repentance; they remain as impenitent as ever (9:20f). Once again, therefore, the readers' expectation will rise: God's patience must now be exhausted; surely the final judgment of the seventh trumpet will now follow. Once again, however, John frustrates this expectation, inserting a long passage between the sixth and seventh trumpets, just as he had done between the sixth and seventh seals. Only when we reach the seven bowls (ch. 16), with which 'the wrath of God is ended' (15:1), do we find an uninterrupted series of total julgments moving rapidly to the final extinction of the evil powers.

In this way John has incorporated the motif of delay into the structure of his book, especially in the form of the parentheses which precede the final seal and the final trumpet. John's understanding of the meaning of the delay we shall expect to find in the content of these parentheses, and also in the episode of the fifth seal (6:9-11), which is his first explicit treatment of the issue of delay.

The martyrs' cry 'How long?' $(6: 10)$ is the traditional apocalyptic question about the delay (Dn. 12:6; Hab. 1:2; Zc. $1: 12$; 2 Baruch $21: 25 ; 4$ Ezra $4: 33,35)$, and the problem from which it arises - the problem of justice and vindication for the martyrs - dates at least from the time of the Maccabean martyrs. The answer to the question is also traditional. The delay will last 'a little while longer' (cf. Is. 26:20; Hg. 2:6; Heb. 10:37; the same motif in Rev. 12:12; 17:10) until the predetermined quota of martyrs is complete. This idea is clearly akin to 2 
Baruch 23:2-5 (discussed above) and even closer to 1 Enoch 47 and 4 Ezra 4:35-37: the last passage may suggest that John has taken over even the depiction of the scene from tradition.

John has therefore taken over this tradition about the meaning of delay without modification, except that he has placed it in the context of the significance of martyrdom according to his work as a whole./53/ For John, Christian martyrdom belongs to the Christian's discipleship of Jesus and the Christian's participation in Jesus' own witness and victory through the cross. In that context the meaning of the delay in this passage goes deeper than the idea of an arbitrarily decreed quota of martyrdoms. In advance of his final victory over evil by power, God has already won the victory of sacrificial suffering, the victory of the slain Lamb. He has done so because he prefers to come to sinners in grace, rather than in merely destructive wrath. But the Lamb's mission and victory must be continued in the followers of the Lamb. Therefore the vindication of the martyrs must wait until all have sealed their witness in blood and God's purposes of grace for the world have been fulfilled through them. The logic of delay here is the logic of the cross. This is the significance which 6:9-11 will gain as the rest of Revelation unfolds the significance of the martyrs.

John does not, in so many words, attribute the delay to the longsuffering of God, but characteristically he pictures this motif. Chapter 7, the parenthesis between the sixth and seventh seals, opens with the picture of the four angels holding back the four winds of the earth, to prevent them from harming the earth: a picture of what Baruch called 'the restraint of wrath' (2 Baruch 59:6). God holds back the release of his final judgment on the world until the angels 'have sealed the servants of God on their foreheads' $(7: 3)$ : in other words, the delay is the period in which men become Christians and are therefore protected from the coming wrath of God.

53. Cf. G. B. Caird, The Revelation of St John the Divine (London: A. \& C. Black, 1966) 87; J. Sweet, Revelation (London: SCM, 1979) 142. 
(Paradoxically, this protection makes them potential martyrs: $7: 14$.

Thus, from the treatment of delay within the seven seals section, we learn that God delays the End for the sake of the church, so that the Lamb may be the leader of a vast new people of God drawn from every nation and sharing his victory through suffering.

The treatment of delay in the seven trumpets section is less easy to follow, because the parenthesis between the sixth and seventh trumpets (10:1 - 11:13) is probably the most obscure passage in Revelation, as the wide variety of suggested interpretations shows. It will be easier to begin with the latter part of it: the story of the two witnesses $(11: 1-13)$. With many commentators, I take this as a parable of the church's mission to the world./54/ The witnesses are two because of the Deuteronomic requirement of two witnesses. They prophesy for three and a half years (11:3) because this is the symbolic figure (taken over from Daniel) which John uses to designate the 'little while' of the delay. Along with many old Testament allusions in the passage, the fact that the witnesses' career is modelled on that of Jesus is noteworthy: their dead bodies lie in the street of the city 'where their Lord was crucified' $(11: 8)$, and after three and a half days they are raised and ascend to heaven. In all probability the final words of the section, 'the rest were terrified and gave glory to the God of heaven' (11:13), are intended to

54. I have discussed this passage briefly in 'The Role of the Spirit in the Apocalypse', EQ 52 (1980) 66-83. Commentators who take a similar view include $\mathrm{H}$. B. Swete, The Apocalypse of St John (London: Macmillan, 21907) 134-41; M. Kiddle, The Revelation of St John (London: Hodder and Stoughton, 1940) 176-206; Caird, op. cit. 133-40; G. R. Beasley-Murray, The Book of Revelation (London: Oliphants, 1974) 176-87; R. H. Mounce, The Book of Revelation (Grand Rapids: Eerdmans, 1977) 222-9; Sweet, op. cit. 181-9. 
indicate sincere repentance./55/ In other words, the men who after the judgments of the six trumpet-blasts remained impenitent $(9: 20 f)$, are now brought to repentance through the suffering witness of the church.

Thus the question with which the original readers may well have concluded chapter 9 - 'Surely God will no longer be patient?' - is answered in chapter 11. Yes, he will be patient because he has another strategy to reach the impenitent, a strategy which began with the sacrifice of the Lamb and continues in the suffering witness of his followers. This is John's further answer to the meaning of delay: not only is the delay for the sake of the church itself (ch. 7), it is for the sake of the church's witness to the world. God's desire that sinners should repent does not stop at simply giving them time, or even at inflicting warning judgments on them; more than that, God actively seeks them in the mission of his son and his church. The delay of the parousia is filled with the mission of the church.

We turn to the problematic chapter 10. The episode of the seven thunders (10:3f) has puzzled the commentators. Probably the seven thunders represent a further series of warning judgments, like the seals and the trumpets. /56/ The command to 'seal up what the seven thunders have said' (10:3) is odd, since John has not written what they said, and he is told not to write it: there is no

55. So Swete, op. cit. 141; R. H. Charles, A Critical and Exegetical Commentary on the Revelation of St John (Edinburgh: T. \& T. Clark, 1920) I, 291f; Caird, op. cit. 139f; L. Morris, The Revelation of St John (London: Tyndale Press, 1969) 152; G. E. Ladd, A Commentary on the Revelation of John (Grand Rapids: Eerdmans, 1972) 139f; Beasley-Murray, op. cit. 187; Sweet, op. cit. 189.

56. J. Day, 'Echoes of Baal's seven thunders and lightnings in Psalm xxix and Habakkuk iii 9 and the identity of the seraphim in Isaiah vi' VT 29 (1979) 143-51, finds a Ugaritic reference to the seven thunders of Baal, which are reflected in Ps. 29. Probably, therefore, John's reference to 'the seven thunders' (10:3) is to a standard apocalyptic image which derives ultimately, like much apocalyptic imagery, from Canaanite mythology. 
document to seal up. Some have suggested that the content of the seven thunders is to be kept secret: John is not to reveal it as he has revealed the content of the seven trumpets./57/ In that case, there are to be further warning judgments, but John's readers are not permitted to know about them. This explanation has the disadvantage of seeming to contradict verse 6 , where the angel swears that there will be no more delay. The alternative suggestion is that the seven thunders represent a further series of warning judgments which are revoked./58/ They are sealed up because they are not to occur. Here 'seal up' is being used as the antithesis of 'open the seal' in chapter 6: if to 'open the seal' means to release the contents of the document into history, then to 'seal up' would mean to prevent the seven thunders being released into history. On this view, verse 6 follows logically: God has cut short the series of warning judgments, and so there will be no more delay before the final judgment of the seventh trumpet.

However, when we turn to the angel's statement in verses 6f, there are further problems. These verses are dependent on Daniel 12:6f, where in reply to Daniel's question 'How long?' the angel swears that it will be 'for a time, two times, and half a time; and that when the shattering of the power of the holy people comes to an end all these things would be accomplished'. John's angel appears to contradict Daniel's: instead of three and a half times (years) of delay, there will be no more delay./59/, But if John means to indicate that the words

57. So Swete, op. cit. 128; w. Hendriksen, More than Conquerors (Iondon: Inter-Varsity Press, 1962) 124; Morris, op. cit. 139; Ladd, op. cit. 143.

58. So A. M. Farrer, The Revelation of St John the Divine (Oxford: Clarendon Press, 1964) 125; Caird, op. cit. 126f; Mounce, op. cit. $209 f$.

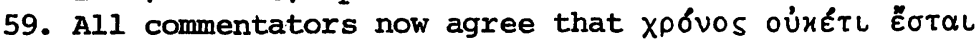
(10:6) should be translated 'there shall be no more delay'. The words probably echo Hab. 2:3. 
of Daniel's angel are inappropriate at this stage of history because there is now to be no more delay, it is strange that, almost immediately (in 11:2f), he goes on to use Daniel's period of three and a half years as his own symbol of the period of delay before the End, during which the power of the new holy people, the church, is being shattered in martyrdom. On grounds of structure /60/ I would reject the suggestion/61/ that in chapter 10 John stands at the end of the three and a half years and then in chapter 11 recapitulates the three and $a$ half years.

We seem, then, to be faced with a straight contradiction. In 10:1-7 we are told that there are to be no more warning judgments and no more delay before the final trumpet-blast which is about to sound./62/ In 11:1-13 (to which 10:8-11 is introductory) we find a delay which is filled with the church's mission: if God has revoked further warning judgments it is not because his patience is ended, but because he purposes to reach men through the church's witness.

I tentatively suggest that John intended this contradiction. The days of the sixth trumpet in which he placed himself are the days in which 'the time is near' $(1: 3 ; 22: 10)$, when the final 'woe' is coming

60. The whole section 10:1 - 11:13 is a unit closely associated with the sixth trumpet $(9: 13-21)$ by means of $9: 12$ and $11: 14$. It is clear from 10:8 that 10: 8-11 succeeds the episode of the seven thunders: John is forbidden to reveal the content of the thunders but instead is given a new commission to prophesy (10:11). This commission is fulfilled initially in 11:1-13, more expansively in chs. 12-14.

61. Hendriksen, op. cit. 125; Morris, op. cit. 140.

62. Some have sought to evade the difficulty by arguing either (1) that 10:6f means only that there will be no more delay before the period of three and a half years (so Charles, op. cit. I, 263, 265f; Caird, op. cit. 127f; Mounce, op. cit. 211; Sweet, op. cit. 127f), or (2) that 10:6f means only that when the seventh trumpet sounds there will be no more delay (so Swete, op. cit. 129). But these are evasions which miss the point of the passage. 
'soon' (11:14), when there is to be no more delay (10:7). And yet, while God does still delay, the church is called to bear her faithful witness in prophecy and martyrdom $(11: 1-13)$. The tension of imminence and delay is here starkly set out, and John makes no attempt to resolve it: he only knows that the church must live in this tension.

To conclude: Revelation maintains the typical apocalyptic tension of imminence and delay, now sharpened and characterized in a peculiarly Christian manner. The imminent expectation focuses on the parousia of the already victorious Christ: and the book ends with the promise, 'I am coming soon', and the church's urgent response, 'Amen. Come, Lord Jesus!' $(22: 20)$. But the manner of the victory which Christ has already won - a sacrificial offering to ransom sinners from every nation (5:9) - gives fresh meaning to the delay, which now becomes the time of the church's universal mission, characterized by suffering witness in discipleship to the crucified Christ. In this way, it should be noticed, the apocalyptic theodicy problem of innocent suffering gains a fresh perspective. Innocent suffering still cries out for eschatological righteousness $(6: 10$; cf. 18:1 - 19:3). But on the other hand, God delays the parousia not simply in spite of his people's sufferings, but actually so that his people may suffer that positive, creative suffering which comes to the followers of the cross of Christ. 